\title{
PENERAPAN MODEL PEMBELAJARAN KOOPERATIF TIPE NUMBERED HEAD TOGETHER BERBANTUAN ALAT PERAGA PAPAN SISI UNTUK MENINGKATKAN KEMAMPUAN KOMUNIKASI MATEMATIS SISWA
}

\section{APPLICATION OF NUMBERED HEAD TOGETHER COOPERATIVE LEARNING MODEL ASSISTED TO THE SIDE BOARD TOOL TO IMPROVE STUDENTS 'MATHEMATIC COMMUNICATION SKILLS}

\author{
Hayatun Nufus \\ ${ }^{1}$ Program Studi Pendidikan Matematika, Universitas Malikussaleh, \\ Jl. Cot Teungku Nie-Reuleut Kecamatan Muara Batu-Aceh Utara, email: hayatun.nufus@unimal.ac.id
}

\begin{abstract}
Abstrak
Penelitian ini bertujuan untuk mengetahui apakah peningkatan kemampuan komunikasi matematis yang diajarkan dengan model pembelajaran kooperatif tipe Numbered Head Together (NHT) berbantuan alat peraga papan sisi lebih baik daripada kemampuan komunikasi matematis yang diajarkan melalui model pembelajaran Direct Intruction. Penelitian ini dilakukan di SMP N 7 Lhoksukon pada kelas VIII tahun ajaran 2019/2020. Penelitian ini merupakan penelitian kuantitatif, jenis penelitian yang digunakan adalah quasi eksperiment. Penelitian ini dilakukan pada dua kelas yaitu kelas eksperimen yang mendapatkan pembelajaran dengan model Numbered Head Together (NHT) sedangkan kelas yang kedua adalah kelas kontrol yang mendapatkan pembelajaran Direct Instruction. Populasi dalam penelitian ini adalah seluruh siswa kelas VIII SMP N 7 Lhoksukon yang terdiri dari 2 kelas. Pengambilan sampel menggunakan teknik probability sampling, diperoleh dua kelas sampel yaitu kelas VIII-A sebagai kelas kontrol dan kelas VIII-B sebagai kelas eksperimen. Data tes dianalisis dengan Mann-Whitney $U$ Test. Instumen pengumpulan data yang digunakan dalam penelitian ini adalah tes kemampuan komunikasi matematis. Analisis data dilakukan dengan menggunakan bantuan SPSS Versi 18. Hasil penelitian menunjukkan bahwa kemampuan komunikasi matematis siswa dengan model pembelajaran Numbered Head Together (NHT) dengan bantuan alat peraga papan sisi lebih baik dari pembelajaran Direct Instruction pada materi Relasi kelas VIII di SMP N 7 Lhoksukon. Hal ini sesuai dengan perolehan nilai Z sebesar $-2,039$ dengan signifikan 0,041. Pada penelitian ini menggunakan uji satu pihak, maka nilai sig tersebut dibagi dua menjadi 0,0205 dimana nilai signifikan tersebut $<0,05$ dengan demikian hipotesis Ho ditolak. Artinya peningkatan kemampuan komunikasi matematis siswa yang memperoleh pembelajaran dengan model Numbered Head Together (NHT) berbantuan alat peraga papan sisi lebih baik dari pada siswa yang memperoleh pembalajaran dengan model pembelajaran langsung.
\end{abstract}

Kata kunci : Kemampuan Komunikasi Matematis dan Model Pembelajaran Numbered Head Together

\begin{abstract}
This study uses a quantitative approach. This type of research is a quasi experiment with sample selection techniques using purposive sampling techniques and using Nonequivalent control group design. This study aims to determine whether increasing the ability to understand mathematical concepts of students taught through the talking stick learning model is better than the ability to understand concepts taught through conventional models. The population in this study were all grade VII students of SMP Negeri 2 Seunuddon, while the sample was two classes. The instrument of data collection in this study was a test of students' understanding of mathematical concepts given before and after the treatment of learning for both classes. Data were analyzed with normality test, homegeneity test, and hypothesis testing aided by SPSS software version 18. The results showed that there was a comparison on the $n$-gain results, namely the experimental class that got learning using the talking stick model was better than the control class that obtained learning using conventional models. Based on the results of testing the hypothesis obtained means rejected and accepted. So it can be concluded that increasing the ability to understand mathematical concepts of students taught through talking stick learning models is better than students who get conventional learning models.
\end{abstract}

Key Words : Understanding Mathematical Concepts and Talking Stick Learning Models 


\section{Pendahuluan}

Pendidikan merupakan suatu kegiatan yang dilakukan manusia untuk merubah dirinya menjadi individu yang lebih baik. Pengertian pendidikan merupakan suatu usaha yang dilakukan untuk mengembangkan kemampuan dan kepribadian individu melalui proses atau kegiatan tertentu (pengajaran, bimbingan atau latihan) serta interaksi individu dengan lingkungannya untuk mencapai manusia yang seutuhnya (insan kamil). Pendidikan berperan penting dalam proses perkembangan mutu suatu bangsa, proses pendidikan terjadi di lingkungan keluarga, sekolah, dan masyarakat[8].

Matematika merupakan salah satu bidang studi yang menduduki peranan penting dalam pendidikan. Banyak ahli yang mengartikan pengertian matematika baik secara umum maupun secara khusus. Matematika merupakan ide-ide abstrak yang diberi simbol-simbol itu tersusun secara hirarkis dan penalarannya deduktif, sehingga belajar matematika itu merupakan kegiatan mental yang tinggi[2]. Pelajaran matematika diberikan kepada semua jenjang pendidikan mulai dari sekolah dasar sampai ke perguruan tinggi. Mengingat pentingnya matematika, maka dalam pengajarannya bukan hanya untuk mengetahui dan memahami apa yang terkandung dalam matematika itu sendiri, tetapi lebih menekankan pada pola berfikir siswa dapat memecahkan masalah secara kritis, logis, kreatif, cermat dan teliti. Matematika bagi sebagian siswa merupakan mata pelajaran yang paling digemari dan menjadi suatu kesenangan. Namun bagi sebagian siswa lain, matematika merupakan salah satu mata pelajaran yang amat berat dan sulit. Bagi sebagian siswa dari kelompok kedua ini beranggapan untuk mendapatkan nilai cukup mereka harus belajar ekstrakeras. Hal ini membuat mereka takut terhadap matematika dan sekaligus malas mempelajarinya[5].

Nasional Council Of Teacher Of Mathematics menyatakan bahwa ada 5 standar yang menggambarkan tujuan dari konten matematika, yaitu dibidang jumlah dan operasi, aljabar, geometri, pengukuran dan analisis serta probabilitas data. Lima standar berikutnya membahas proses penyelesaian masalah, penalaran dan bukti, koneksi, komunikasi dan representasi. Salah satu standar proses pembelajaran adalah komunikasi (communication). Komunikasi dalam hal ini adalah tidak hanya sekedar komunikasi secara lisan tetapi juga komunikasi secara tertulis. [6] berpendapat bahwa dalam pembelajaran matematika, seorang siswa yang sudah mempunyai pemahaman matematika dituntut juga untuk bisa mengkomunikasikannya, agar pemahamannya tersebut bisa dipahami orang lain. Dengan mengkomunikasikan pikiran, gagasan dan ide-ide matematikanya kepada orang lain, seorang siswa bisa meningkatkan pemahaman matematikanya dan meningkatkan prestasi belajar matematikanya. Ini berarti, komunikasi dalam matematika dapat menolong guru memahami kemampuan peserta didik dalam membangun dan menerapkan pemahamannya tentang konsep dan proses matematika yang mereka pelajari, jadi jelaslah bahwa komunikasi matematis merupakan kemampuan yang penting dikembangkan dalam pembelajaran matematika[6].

Berdasarkan hasil wawancara peneliti dengan guru bidang studi Matematika di kelas VIII yaitu ibu Aisyah, S.Pd bahwasanya SMP N 7 Lhoksukon merupakan sekolah yang menerapkan berbagai macam model dan metode untuk menunjang suatu keberhasilan siswa dalam proses belajar mengajar. Salah satu model yang diterapkan khususnya pada pembelajaran matematika yaitu model pembelajaran secara langsung (Direct Intruction). Guru tersebut menyatakan bahwa belum pernah menerapkan soal tes kemampuan komunikasi matematis, guru tidak terbiasa mengaitkan media pembelajaran yang berkaitan dengan kehidupan sehari-hari, sehingga siswa kurang termotivasi dan tertarik untuk belajar, sebagian besar siswa mengalami kesulitan dalam memberikan penjelasan secara tepat, jelas, dan logis atas sejumlah soa, siswa lebih sering mengalami kesulitan dalam mengungkapkan alasan atas setiap jawabannya. Hal ini terbukti saat peneliti melakukan tes soal pendahuluan kepada siswa kelas VIII di SMP Negeri 7 Lhoksukon, yang didapatkan hasil bahwa siswa siswa tidak mampu mengkomunikasikan permasalahan yang diberikan oleh guru dimana hasil dari jawaban siswa tersebut masih kurang tepat serta langkah-langkah dalam menyelesaikan soal yang diberikan menunjukkan bahwa siswa tersebut masih sangat kurang dalam kemampuan komunikasi matematis. Hal ini dapat dilihat bahwa siswa tidak menjelaskan ide, situasi dan relasi matematika ke dalam gambar, siswa tidak memahami dan mengevaluasi ide matematika dama menyelasaikan permasalahan sehari-hari.

Berdasarkan permasalahan yang ada, maka salah satu cara yang dapat dilakukan untuk mengatasi permasalahan ini yaitu dengan adanya penerapan model pembelajaran yang bisa mengaktifkan siswa dan mengembangkan minat belajar siswa serta meningkatkan kemampuan komunikasi matematis. Untuk meningkatkan kemampuan komunikasi matematis siswa, peneliti mencoba untuk menerapkan model pembelajaran kooperatif dengan model Numbered Head Together (NHT) dengan bantuan alat peraga papan sisi. Menurut [4] Numbered Head Together (NHT) merupakan suatu rangkaian penyampaian materi dengan menggunakan kelompok sebagai wadah dalam menyatukan persepsi/pikiran siswa terhadap pertanyaan yang dilontarkan atau diajukan guru, yang kemudian akan dipertanggungjawabkan oleh siswa sesuai dengan nomor permintaan guru dari masing-masing kelompok.

Hubungan model pembelajaran Numbered Head Together (NHT) dengan alat peraga papan sisi yaitu pada Fase pengajuan pertanyaan, siswa menyaksikan penerapan soal pada alat peraga papan sisi dengan cara pendidik memberikan contoh soal yang hampir sama dengan soal di LAS dengan cara menanyakan langsung kepada siswa megenai buah-buahan kesukaan dari siswa tersebut. Alat peraga merupakan salah 
Hal : $29-35$

satu dari media pendidikan adalah alat untuk membantu proses belajar mengajar agar proses komunikasi dapat berhasil dengan baik dan efektif, semua atau segala sesuatu yang bisa digunakan dan dapat dimanfaatkan untuk menjelaskan konsep-konsep pembelajaran dari materi yang bersifat abstrak atau kurang jelas menjadi nyata dan jelas sehingga dapat merangsang pikiran, perasaan, perhatian serta minat para siswa yang menjurus kearah terjadinya proses belajar mengajar[1]. Berdasarkan latar belakang masalah yang telah penulis uraikan di atas, maka penulis mengangkat judul penerapan model pembelajaran kooperatif tipe Numbered Head Together (NHT) berbantuan alat peraga papan sisi untuk meningkatkan kemampuan komunikasi matematis siswa kelas VIII pada materi Relasi di SMP N 7 Lhoksukon" .

Berdasarkan latar belakang masalah tersebut, rumusan masalah pada penelitian ini adalah: "Apakah ada pengaruh model pembelajaran kooperatif tipe Numbered Head Together (NHT) berbantuan alat peraga papan sisi terhadap kemampuan komunikasi matematis siswa kelas VIII pada materi Relasi di SMP N 7 Lhoksukon?..

\section{Metode Penelitian}

Penelitian ini menggunakan pendekatan kuantitatif, dimana data yang peneliti kumpulkan dalam bentuk angka yang akan diuji menggunakan metode statistik. Penelitian ini dilaksanakan di SMP Negeri 7 lhoksukon dengan mengambil sampel penelitian 2 kelas, yaitu kelas kontrol dan kelas eksperimen yang dilaksanakan pada tahun pelajaran 2019/2020. Jenis penelitian yang digunakan adalah Quasi Experimental Design yaitu desain yang mempunyai kelompok kontrol, tetapi tidak dapat berfungsi sepenuhnya untuk mengontrol variabelvariabel luar yang mempengaruhi pelaksanaan eksperimen. Adapun design rancangan penelitian yang digunakan adalah non equivalent control group design. Desain rancangannya sebagai berikut:

Tabel 1 Rancangan Penelitian

\begin{tabular}{|c|c|c|c|}
\hline Model Pembelajaran & Pretest & Perlakuan & Posttest \\
\hline $\begin{array}{c}\text { Numbered head together } \\
\text { Pembelajaran Direct } \\
\text { Intruction }\end{array}$ & $\mathrm{O}_{1}$ & $\mathrm{X}$ & $\mathrm{O}_{2}$ \\
\hline $\mathrm{O}_{3}$ & & $\mathrm{O}_{4}$ \\
\hline
\end{tabular}

Keterangan:

Modifikasi [8]

$\mathrm{O}_{1}=$ Pretest untuk kelas Numbered head together

$\mathrm{O}_{3}=$ Pretest untuk kelas Pembelajaran Direct Intruction

$\mathrm{X}=$ Perlakuan pembelajaran Numbered head together

$\mathrm{O}_{2}=$ Posttest untuk kelas Numbered head together

$\mathrm{O}_{4} \quad=$ Posttest untuk kelas Pembelajaran Direct Intruction

Adapun yang menjadi populasi dalam penelitian ini adalah seluruh siswa kelas VII SMP Negeri 7 Lhoksukon pada semester ganjil tahun ajaran 2019/2020. Pemilihan sampel pada penelitian ini menggunakan teknik Purposive sampling. purposive sampling merupakan teknik sampling yang digunakan peneliti jika peneliti mempunyai pertimbangan-pertimbangan tertentu dan dalam pengambilan sampelnya atau penentuan sampel untuk tujuan tertentu [6]. Sampel tersebut merupakan bagian dari kelas VIII/B sebagai kelas eksperimen yaitu menggunakan model pembelajaran Numbered head together dan kelas VIII/A sebagai kelas kontrol yaitu menggunakan model Pembelajaran langsung. Instrumen penelitian merupakan alat yang digunakan untuk mengumpulkan data yang diperlukan dalam suatu penelitian. Instrumen penelitian berupa tes kemampuan komunikasi matematis. Menurut [6], tes sebagai instrumen pengumpulan data adalah serangkaian pertanyaan atau latihan yang digunakan untuk mengukur keterampilan pengetahuan, intelegensi, kemampuan atau bakat yang dimiliki oleh individu atau kelompok. Penelitian ini, instrument yang digunakan adalah tes kemampuan komunikasi matematis siswa, untuk memperoleh data yang diperlukan dalam penelitian, peneliti memberikan tes kemampuan komunikasi matematis terdiri dari 4 butir soal essay yang akan diberikan kepada kelas eksperimen dan kelas kontrol sebelum dan setelah selesai semua proses pembelajaran mengenai materi Relasi.

\section{Hasil Penelitian dan Pembahasan}

\section{Hasil Penelitian}

Analisis data $\mathrm{N}$-Gain bertujuan untuk mengetahui perbedaan nilai hasil belajar siswa antara sebelum menggunakan media dengan setelah menggunakan media, data yang di pakai untuk melihat peningkatan 
Hal : $29-35$

kemampuan komunikasi matematis siswa adalah data hasil Preetest dan Posttest. Adapun rangkuman rataan skor N-Gain kemampuan komunikasi matematis siswa adalah sebagai berikut.

Tabel 5. Rataan dan Klasifikasi $\mathbf{N}$-Gain Kemampuan komunikasi Matematis

\begin{tabular}{|c|c|c|}
\hline Kelas & Rataan $\mathbf{N}-$ gain & klasifikasi \\
\hline Eksperimen & 0,6522 & Sedang \\
\hline kontrol & 0,4426 & Sedang \\
\hline
\end{tabular}

Berdasarkan tabel di atas dapat dilihat bahwa rataan $N$-Gain pada kelas eksperimen adalah 0,6522 dan berada pada kategori sedang, sedangkan rataan $N$-Gain pada kelas kontrol adalah 0,4426 yang berada pada kategori sedang.

Uji Normalitas skor N-Gain

Uji normalitas bertujuan untuk mengetahui apakah data yang diperoleh dari hasil penelitian adalah data yang berdistribusi normal atau tidak. Uji normalitas skor $N$-gain kemampuan komunikasi matematis ini menggunakan uji shapiro-wilk dengan bantuan SPSS Versi 18 . hipotesis yang di uji untuk mengetahui normalitas skor $N$-gain kemampuan komunikasi matematis adalah:

$H_{0}=$ kelompok data dari populasi yang berdistribusi normal

$H_{a}=$ kelompok data dari populasi yang tidak berdistribusi normal

kriteria pengujiannya, apabila nilai signifikan $>0,05$ maka $\mathrm{H}_{0}=$ diterima artinya data berdistribusi normal

Tabel 6 Hasil Uji Normalitas Skor $\mathbf{N}$-Gain Kemampuan Pemahaman Konsep Matematis Tests of Normality

\begin{tabular}{l|r|r|r|r|r|r|}
\hline \multirow{2}{*}{ Kelompok } & \multicolumn{3}{|c|}{ Kolmogorov-Smirnov $^{\mathrm{a}}$} & \multicolumn{3}{c|}{ Shapiro-Wilk } \\
\cline { 2 - 7 } & Statistic & \multicolumn{1}{c|}{ Df } & \multicolumn{1}{c|}{ Sig. } & Statistic & \multicolumn{1}{c|}{ Df } & \multicolumn{1}{c|}{ Sig. } \\
\hline eksperimen &, 195 & 19 &, 056 &, 893 & 19 &, 037 \\
Kontrol &, 134 & 18 &, $200^{*}$ &, 928 & 18 &, 182 \\
\hline
\end{tabular}

Dari tabel 4.7 diperoleh nilai sig 0,037 dikelas eksperimen dan 0,182 di kelas kontrol. Berdasarkan pengujian hipotesis untuk kelas eksperimen nilai signifikannya kurang dari 0,05 maka $\mathrm{H}_{0}=$ di tolak dan kelas kontrol nilai signifikannya lebih dari 0,05 sehingga $\mathrm{H}_{0}$ diterima, artinya untuk kelas eksperimen tidak berdistribusi normal sedangkan kelas kontrol berdistribusi normal.

\section{Uji Non Parametrik}

Berdasarkan hasil uji normalitas yang telah dilakukan, diperoleh bahwa pada kelas eksperimen data berdistribusi tidak normal sedangkan pada kelas kontrol data berdistribusi normal. Maka dari itu dilanjutkan ke pengujian non parametrik. Selanjutnya untuk membutuktikan peningkatan kemampuan komunikasi matematis siswa kelas eksperimen lebih baik dari kelas kontrol dilakukan uji non parametrik dengan bantuan SPSS Versi 18 menggunakan uji Mann-Whitneya.

Dirumuskan hipotesisnya yaitu sebagai berikut:

$\mathrm{H}_{0}: \mu_{1}=\mu_{2}$

peningkatan kemampuan komunikasi matematis yang diajarkan melalui model pembelajaran kooperatif tipe Numbered Head Together (NHT) berbantuan alat peraga papan sisi sama denga kemampuan komunikasi matematis yang diajarkan melalui model Direct Intruction kelas VIII pada materi Relasi di SMP N 7 Lhoksukon.

$$
\mathrm{Ha}: \mu_{1}>\mu_{2}
$$

peningkatan kemampuan komunikasi matematis yang diajarkan melalui model pembelajaran kooperatif tipe Numbered Head Together (NHT) berbantuan alat peraga papan sisi lebih baik daripada kemampuan 
Hal : $29-35$

komunikasi matematis yang diajarkan melalui model Direct Intruction kelas VIII pada materi Relasi di SMP N 7 Lhoksukon.

Keterangan:

$$
\begin{aligned}
& \mu_{1}=\text { rank skor } N \text {-gain kemampuan komunikasi matematis kelas eksperimen } \\
& \mu_{2}=\text { rank skor } N \text {-gain kemampuan komunikasi matematis kelas kontrol }
\end{aligned}
$$

Kriteria pengujiannya, apabila nilai signifikasi $<0,05$ maka $\mathrm{H}_{0}$ ditolak artinya peningkatan kemampuan komunikasi matematis siswa dengan penerapan model pembelajaran Numbered Head Together (NHT) lebih baik dari pada pembelajaran Direct Intruction.

Tabel 4.8 Hasil Uji Non Parametrik Kemampuan Komunikasi Matematis

Test Statistics ${ }^{b}$

\begin{tabular}{|l|r|}
\hline & \multicolumn{1}{|c|}{ Ngain } \\
\hline Mann-Whitney U & 104,000 \\
Wilcoxon W & 275,000 \\
Z & $-2,039$ \\
Asymp. Sig. (2-tailed) &, 041 \\
Exact Sig. [2*(1-tailed &, $042^{\mathrm{a}}$ \\
Sig.)] & \\
\hline
\end{tabular}

Berdasarkan hasil uji Mann-Whitney diperoleh nilai Z sebesar -2,039 dengan signifikan 0,041. Pada penelitian ini menggunakan uji satu pihak, maka nilai sig tersebut dibagi dua menjadi 0,0205 dimana nilai signifikan tersebut < 0,05 dengan demikian hipotesis Ho ditolak. Artinya peningkatan kemampuan komunikasi matematis siswa yang memperoleh pembelajaran dengan model Numbered Head Together (NHT) berbantuan alat peraga papan sisi lebih baik dari pada siswa yang memperoleh pembalajaran dengan model Direct Intruction.

\section{Uji Hipotesis}

Setelah mengetahui bahwa data yang diperoleh berdistribusi normal dan homogen maka dilanjutkan pada pengujian hipotesis atau uji-t. Uji hipotesis ini bertujuan untuk mengetahui apakah kemampuan pemahaman konsep matematis siswa yang diajarkan menggunakan model pembelajaran Numbered Head Together (NHT) lebih baik daripada kemampuan komunikasi matematis siswa yang diajarkan menggunakan Direct Intruction. Pengujian hipotesis ini dilakukan dengan menggunakan Independent Samples Test yang berbantuan software SPSS versi 18 dengan kriteria pengujiannya adalah terima $\mathrm{H}_{0}$ apabila nilai signifikan lebih dari taraf signifikan ( $\alpha=0,05$ ) dan tolak $\mathrm{H}_{0}$ apabila nilai signifikan kurang dari 0,05. Adapun hipotesis pada penelitian ini adalah:

$H_{0}: \mu_{1}=\mu_{2} \quad$ : Rata-rata peningkatan kemampuan kemampuan komunikasi matematis siswa dengan model pembelajaran Numbered Head Together (NHT) secara signifikan sama dengan rata-rata peningkatan kemampuan kemampuan komunikasi matematis siswa dengan Direct Intruction kelas VIII pada materi Relasi di SMP N 7 Lhoksukon.

$\mathrm{Ha}: \mu_{1}>\mu_{2}$ : Rata-rata peningkatan kemampuan kemampuan komunikasi matematis siswadengan model pembelajaran Numbered Head Together (NHT) lebih baik secara signifikan daripada rata-rata peningkatan kemampuan kemampuan komunikasi matematis siswa dengan Direct Intruction kelas VIII pada materi Relasi di SMP N 7 Lhoksukon.

Keterangan:

$\mu_{1}$ : Rataan skor $N$-Gain kemampuan kemampuan komunikasi matematis siswa kelas eksperimen

$\mu_{2}$ : Rataan skor $N$-Gain kemampuan kemampuan komunikasi matematis siswa kelas kontrol 
Hal : $29-35$

Adapun hasil uji hipotesis skor N-Gain kemampuan kemampuan komunikasi matematis tersebut disajikan dalam tabel berikut.

Tabel 7 Uji Hipotesis Skor N-Gain Kemampuan kemampuan komunikasi matematis

\begin{tabular}{|c|r|c|c|}
\hline \multicolumn{2}{|c|}{$\begin{array}{c}\text { t-test for Equality of Means } \\
\text { (Equal Variances Assumed) }\end{array}$} & \multirow{2}{*}{ Keterangan } \\
\hline $\mathrm{T}$ & $d f$ & Sig. (1-tailed) & \\
\hline 11,629 & 46 & 0,000 & $\mathrm{H}$ \\
\hline
\end{tabular}

Dari tabel diatas diperoleh hasil uji t yaitu 0,000 yang artinya kurang dari 0,005 sehingga $\mathrm{H}_{0}$ ditolak dan $\mathrm{H}_{\mathrm{a}}$ diterima. Dapat disimpulkan bahwa kemampuan kemampuan komunikasi matematis yang diajarkan menggunakan model pembelajara Numbered Head Together (NHT) lebih baik secara signifikan daripada kemampuan kemampuan komunikasi matematis yang diajarkan menggunakan model pembelajaran Direct Intruction.

\section{Pembahasan}

Proses pembelajaran yang berlangsung harus sesuai dengan tujuan pembelajaran yang diharapkan oleh sebuah pendidkan dan pelatihan. Penelitian ini merupakan penelitian quasi-eksperimen yang bertujuan untuk mengetahui adanya peningkatan kemampuan konunikasi matematis siswa pada proses pembelajarn kooperatif tipe Numbered Head Together (NHT) berbantuan alat peraga papan sisi dengan metode diskusi pada siswa kelas VIII SMP N 7 Lhoksukon, untuk mengetahui apakah proses pembelajaran kooperatif tipe Numbered Head Together (NHT) dapat meningkatkan kemampuan komunikasi matematis siswa. Hal ini dilihat dari rataan skor N-Gain yang didapat pada kedua kelas, yaitu kelas eksperimen mendapatkan hasil 0,69 sedangkan pada kelas kontrol didapatkan hasil 0,30. Setelah skor rataan $N$-Gain diperoleh maka selanjutnya dilakukan uji normalitas yang bertujuan untuk melihat apakah skor $N$-Gain tersebut berdistribusi normal atau tidak. Kemudian setelah diketahui bahwa skor rataan $\mathrm{N}$-Gain tersebut berdistribusi normal, maka dilanjutkan pengujian homegenitas dan yang terakhir dilakukannya pengujian hipotesis atau uji t.

Berdasarkan hasil uji hipotesis diperoleh hasil signifikannya 0,000 maka tolak $\mathrm{H}_{0}$ terima $\mathrm{H}_{\mathrm{a}}$ yang berarti $0,000<0,05$. Sehingga dapat disimpulkan bahwa Kemampuan komunikasi matematis siswa dengan menggunakan model pembelajaran NHT (Numbered Head Together) lebih baik secara signifikan daripada kemampuan pemahaman komunikasi matematis siswa dengan menggunakan menggunakan model pembelajaran Direct Intruction pada materi Relasi di SMP N 7 Lhoksukon..

\section{Kesimpulan}

Berdasarkan hasil penelitian yang telah dilaksanakan maka dapat diambil kesimpulan pembelajaran dengan menggunakan model pembelajaran kooperatif tipe NHT (Numbered Head Together) berbantuan alat peraga papan sisi dapat meningkatkan kemampuan komunikasi matematis siswa pada materi Relasi, serta memiliki perbedaan dalam peningkatan rata-rata nilai kemampuan komunikasi matematis siswa jika dibandingkan dengan pembelajaran Direct Intruction pada materi Relasi, diajarkan melalui model pembelajaran kooperatif tipe Numbered Head Together (NHT) berbantuan alat peraga papan sisi lebih baik daripada kemampuan komunikasi matematis yang diajarkan melalui model Direct Intruction kelas VIII pada materi Relasi di SMP N 7 Lhoksukon.

\section{Daftar Pustaka}

[1] Fauziyyah, L,. A. 2018. Pengaruh Penggunaan Alat Peraga Terhadap Hasil Belajar Pada Mata Pelajaran IImu Pengetahuan Alam Kelas IV Sekolah Dasar Negeri 2 Rulung Raya Natar Lampung Selatan Tahun Ajaran 2016/2017. Skripsi, Lampung: Universitas Islam Negeri Raden Intan Lampung.

[2] Hasratuddin. 2014. Pembelajaran Matematika Sekarang dan yang Akan Datang Berbasis Karakter".Jurnal didaktik matematika. http://www.jurnal.unsyiah.ac.id/DM/article/view/2075/2029

[3] Hayatun, Nufus. 2013. Peningkatan kemampuan pemecahan masalah dan komunikasi matematis siswa SMP Negeri Lhokseumawe. Tesis. Universitas Negeri Medan

[4] Istarani. 2014. 58 Model Pembelajaran Inovatif.Medan:Media Persada 
Hal : $29-35$

[5] Ariani, Nurlina. 2016. Perbedaan Hasil Belajar Menggunakan Metode Ekspositori Berbasis Peta Konsep Dengan Metode Ekspositori Peta Pikiran Pada Pokok Bahasan Dimensi Tiga Di Kelas X Sma Negeri 1 Pangkatan Tahun Pembelajaran 2015/2016. JPMS. Vol.2 no.2 nopember 2016. pp.19-24.

[6] NCTM. 2000. Principles and Standards For School Mathematics

[7] Riduwan. 2012. Belajar Mudah Penelitian Untuk Guru-Karyawan dan Peneliti Pemula. Bandung: Alfabeta

[8] Sary, Y., N., E. 2018 Buku Mata Ajar Evaluasi Pendidikan. Yogyakarta: Deepublish

[9] Sugyono. 2016. Metode Penelitian Kuantitatif, Kualitatif, dan R\&D. Bandung: Alfabeta. 
